\title{
The effect of the plyometric training program on sportive performance parameters in young soccer players
}

\author{
Tahsin INCE, Onder DAGLIOGLU
}

Gaziantep University, School of Physical Education and Sports, Gaziantep, Turkey

Address correspondence to O. Daglioglu, e-mail: daglioglu@hotmail.com

\begin{abstract}
The studies that aim to bring together the strength and the speed of movement are called plyometric trainings. Our aim in this study is to be able to show the effect of plyometric training program on sportive performance parameters in young soccer players and to make recommendations for coaches and sportsmen on sportive training and training planning from this point. Twenty-four male soccer players aged 17-22 making regular soccer training participated in the study. Two different groups were formed as experimental and control groups and a plyometric training program was applied to the experimental group for 3 days a week for 8 weeks. Both groups continued their normal soccer training. Height, weight, body mass index (BMI), body fat percentage (BFP), aerobic capacity $\left(\mathrm{VO}_{2}\right.$ max), anaerobic capacity, speed and flexibility were measured before and after training. The trainings known as drop jump, box jump, squat jump, split squat jump, overhead slam and plyometric push-up were applied to the plyometric training group. Vertical jump test was used for anaerobic capacity measurement. Flexibility test (Sit and Reach test) and speed test $(30 \mathrm{~m})$ were applied. For statistical analysis, Paired Sample t-test was used in group comparisons and Independent Sample t-test was used for intergroup comparisons. BFP, anaerobic capacity, $\mathrm{VO}_{2} \mathrm{max}, \mathrm{speed}$ and elasticity values were found to be significant after the plyometric training program of the experimental group $(\mathrm{p}<0.05)$. BFP and $\mathrm{VO}_{2}$ max values of the control group were significant $(\mathrm{p}<0.05)$. When the groups were compared, anaerobic capacity, speed and flexibility values were found to be significant in favor of the experimental group $(\mathrm{p}<0.05)$. There was no significant difference in weight, BMI, BFP and $\mathrm{VO}_{2}$ max values ( $\mathrm{p}>0.05$ ). As a result of our research, the plyometric training program applied to young soccer players is considered to have a positive effect on sportive performance parameters. It can be said that regular and programmed plyometric training improves sportive performance positively.
\end{abstract}

Keywords: Plyometric training, Sportive performance, Soccer.

\section{INTRODUCTION}

Soccer is one of the most popular sport branches in the world. The popularity of the soccer branch, which can reach very huge populations in the world and our country, is increasing day by day (22). Therefore, soccer has become a way of life by dealing with sports politics, school sports and clubs (21). Soccer can show performances having changeable loading and resting interval with respect to the technical and tactical characteristics (6).

As in all branches, physical and physiological development of basic motor skills is at the forefront in soccer. Optimal training should meet the physiological and physical needs of both the sportsman and the sports branch. The goal of the training program applied to the sportsmen is to develop their physiological and physical efficiencies of them and improve sportive performance (7). Soccer is a sports branch that is highly aerobic in terms of energy systems and contains high-intensity intermittent trainings including anaerobic activities. For this reason, lower extremity strength, endurance, strength and speed are performance components for soccer player (18). Exercises that aim to combine strength, speed of motion and explosive strength are described as plyometric trainings (10). The goal of plyometric training is to keep the time of contact with the ground as low as possible when jumping or on the move. A tonus event occurs in the tendons and connective tissues. This allows the potential elastic energy to appear. This energy is stored in eccentric contraction, and a large strength is exerted by the effect of gravity during concentric contraction (28).

Plyometric trainings may not be a miracle, but it can be thought as an important form of training that allows fast reactions and explosive strength to develop. It plays an important role in determination of fast strength and strength performance in the 
soccer branch and sports branches which need to change direction quickly. In soccer trainings, sportsmen need plyometric trainings to improve their strength, fats strength, leg strength and jumping efficiency. In addition, these trainings are effective in increasing the athletic performance of the sportsmen. Recently, plyometric trainings have been included in the strength exercises (13).

Our aim in this study is to be able to show the effect of sportive performance parameters of plyometric training program on young soccer players and to be able to give recommendations for coaches and sportsmen on sportive training and training planning from this point.

\section{MATERIAL \& METHOD}

\section{Selection of Study Group}

Twenty-four male soccer players aged 17-22 making regular soccer training participated in the study. Two different groups were formed as experimental and control groups and a plyometric training program was applied to the experimental group for 3 days a week for 8 weeks. Both groups continued their normal soccer training. Information indicating that the research is appropriate for the ethics committee was informed to Gaziantep University Clinical Research Ethics Committee and Ethics Committee Approval was obtained. The details of how to conduct the research were explained to the subjects in detail through Subject Notification Form. Signed forms showing that they are volunteers were obtained. During the study, they were asked not to take supplements and not to do heavy exercises.

\section{Study Protocol}

Height, body mass index (BMI), body fat weight, body fat percentage (BFP), aerobic capacity $\left(\mathrm{VO}_{2}\right.$ max), anaerobic capacity, speed and elasticity were measured before and after the plyometric training. To find the aerobic strength of the subjects, Ramp protocol was applied in a progressively increasing cardiopulmonary exercise test in cycling ergometry. BMI and BFP were measured by Bioelectrical Impedance analysis method. Vertical jump test was used for anaerobic strength measurement. Flexibility test (Sit and Reach) and speed test $(30 \mathrm{~m})$ were applied. Measurements were performed in Physiology Laboratory of Gaziantep University Physical Education and Sports High School.

\section{Plyometric Training Program}

A total of 8-week plyometric training program for lower and upper limbs consisted of 4 weeks of moderate intensity training ( 3 sets $\mathrm{x} 10$ repetitions and $90 \mathrm{sec}$ rests) and 4 weeks of high intensity training (4 sets $x 10$ repetitions and 90 seconds rests) for 3 days a week besides soccer trainings was applied to the experimental group. The trainings known as drop jump, box jump, squat jump, split squat jump, overhead slam and plyometric push-up were applied to the plyometric training group. Subjects were told that every exercise movement should be performed at maximal level and should be taken down softly after the jump. Subjects were warned not to do any heavy exercise except soccer training and plyometric training. Sportive performance measurements were taken 1 day before plyometric training and 1 day after the training was over.

\section{Data Collection}

\section{Anthropometric Measurements}

The weights of sportsmen were measured by a weighbridge having $0.1 \mathrm{~kg}$ precision and the heights were measured by a digital length measuring instrument. The subjects were participated in the measurements with shorts, T-shirts and bare feet. BMI measurements were calculated by dividing the body weight into the square of the height in meters (16)

\section{$\mathrm{VO}_{2}$ max Measurement}

Ramp protocol in the gradually increasing cardiopulmonary exercise test in the electromagnetic cyclometer ergometer (MEC PFT SYSTEMS ERGO) was applied to the subjects participating in the study. The protocol was resting for 3 minutes, 3 noload pedals (warm-up) and increased 25 watts per minute. The pedal stroke was stable at approximately $60-70 \mathrm{rpm}$. The test was maintained until the level that the subjects couldn't tolerate the increasing load. When the test was over, the pedal load is reduced to 25 watts, pedaling was continued for 3 more minutes and the test was terminated. $\mathrm{VO}_{2}$ max was measured by this test (2).

\section{Body Fat Percentage Measurement}

Body fat percentages of the subjects were measured using BIA (Tanita Body Fat Analyzer, model TBF 300) technique. While taking the measurements, the weight of the clothes is reduced, 
the board touched by feet was wiped with a damp cloth and the conductivity is increased.

\section{0-meter Sprint Test}

The subjects performed short sprints after 10 minutes of active warming. Afterwards, the subjects taken to rest 1-meter behind the starting line were asked to start when they felt ready. Three-minutes rest interval was given between the tests and 2 tests were performed $(19,32)$. The subject's track finish time was recorded in seconds to the subject information form. At the end of the measurement, both grades were recorded and maximum scores were selected for evaluation.

\section{Vertical Jump Test}

As testing tools; chalk, meter and cardboard prepared to hang to the wall were used. The aim of the test is to measure the jump power of the subject. While the subject was placed by reclining in side position to the cardboard hanging on the wall as written in $\mathrm{cm}$ and lifting the arm as far as possible (without lifting the soles), the alignment of the fingertip of this arm was detected and recorded in the cardboard. The middle finger of the hand touching the cardboard was immersed in chalk dust and the subject was touched to the highest point where he could jump and touch with the help of his arms. The distance between the first reach and jump was recorded in $\mathrm{cm}$. For the test, two rights were given each subject and the best grade was recorded. Lewis's formula was used for the calculation of anaerobic capacity $(26,32)$.

$$
\begin{aligned}
& \text { Anaerobic Capacity: } \sqrt{4} \text { 4.9.(body mass) } \sqrt{ } \mathrm{D} \\
& \text { D:(Jump height) }
\end{aligned}
$$

\section{Flexibility Measurements}

Flexibility measurement was made using a situp stand. For this measurement, the subject sat with his bare feet in front of the stand and based his soles flat to the stand. The body was bowed forward, lay forward without bending knees and tried to stay at the farthest place the subject can reach. The maximum distance reached on the scale on the stand on which the flexibility measurement was made was accepted as the flexibility value in centimeters. The test was repeated twice and the higher value was accepted (32).

\section{Statistical Analysis}

SPSS statistical program (SPSS for Windows, version 20.0, SPSS Inc. Chicago, Illinois, USA) was used in the analysis of the data. The Independent Samples T Test was used to evaluate the significance between the experimental and control groups. Paired Samples T Test was applied for intra-group comparisons. Statistical results were evaluated at $\mathrm{p}<0.05$ significance level.

\section{RESULTS}

\begin{tabular}{|c|c|c|c|c|c|}
\hline \multirow{2}{*}{ Variable } & Pre-test & Post-test & \multirow{2}{*}{$\mathrm{df}$} & \multirow{2}{*}{$\mathrm{t}$} & \multirow{2}{*}{$\mathrm{p}$} \\
\hline & Mean \pm SD & Mean \pm SD & & & \\
\hline Age (year) & $19.16 \pm 0.95$ & $19.16 \pm 0.95$ & - & - & - \\
\hline Height $(\mathrm{cm})$ & $174.62 \pm 6.86$ & $174.62 \pm 6.86$ & - & - & - \\
\hline Weight $(\mathrm{kg})$ & $72.64 \pm 5.12$ & $71.85 \pm 5.72$ & 11 & 1.452 & 0.681 \\
\hline BMI $\left(\mathrm{kg} / \mathrm{m}^{2}\right)$ & $23.98 \pm 1.52$ & $23.11 \pm 1.45$ & 11 & 0.389 & 0.745 \\
\hline $\mathrm{BFP}(\%)$ & $13.04 \pm 1.85$ & $12.14 \pm 1.76$ & 11 & 4.322 & $0.001^{*}$ \\
\hline Anaerobic Power (kgm/sn) & $122.56 \pm 4.87$ & $133.85 \pm 6.45$ & 11 & -4.546 & $0.001^{*}$ \\
\hline $\mathrm{VO}_{2} \max (\mathrm{ml} / \mathrm{kg} / \mathrm{dk})$ & $48.39 \pm 1.85$ & $51.32 \pm 1.91$ & 11 & -5.326 & $0.001^{*}$ \\
\hline Speed $30 \mathrm{~m}(\mathrm{sn})$ & $4.79 \pm 0.22$ & $4,23 \pm 0.16$ & 11 & 6.219 & $0.001^{*}$ \\
\hline Flexibility $(\mathrm{cm})$ & $26.12 \pm 3.89$ & $29.45 \pm 2.56$ & 11 & -6.225 & $0.001^{*}$ \\
\hline
\end{tabular}

Table 1. Pre-test and post-test analysis results of the experimental group

* $\mathrm{p}<0.05$

Table 1 provides a comparison of pre-test and post-test measurement results of the data obtained after the plyometric training program applied to the experimental group. After the plyometric training program applied to the experimental group, the values of BFP, Anaerobic Power, $\mathrm{VO}_{2}$ max, Speed and Flexibility were found significant $(p<0.05)$.
There was no significant difference in the other data of the experimental group ( $\mathrm{p}>0.05)$. 
Table 2. Pre-test and post-test analysis results of the control group

\begin{tabular}{|c|c|c|c|c|c|}
\hline \multirow{2}{*}{ Variable } & Pre-test & Post-test & \multirow{2}{*}{$\mathrm{df}$} & \multirow{2}{*}{$\mathrm{t}$} & \multirow[b]{2}{*}{$\mathrm{p}$} \\
\hline & Mean \pm SD & Mean \pm SD & & & \\
\hline Age (year) & $20.42 \pm 0.81$ & $20.42 \pm 0.81$ & - & - & - \\
\hline Height $(\mathrm{cm})$ & $175.13 \pm 4.22$ & $175.13 \pm 4.22$ & - & - & - \\
\hline Weight $(\mathrm{kg})$ & $72.56 \pm 3.85$ & $72.19 \pm 2.52$ & 11 & 1.183 & 0.471 \\
\hline BMI $\left(\mathrm{kg} / \mathrm{m}^{2}\right)$ & $23.64 \pm 2.08$ & $23.26 \pm 2.14$ & 11 & 0.459 & 0.558 \\
\hline BFP $(\%)$ & $13.44 \pm 1.16$ & $12.87 \pm 1.91$ & 11 & 0.574 & $0.014^{*}$ \\
\hline Anaerobic Power (kgm/sn) & $123.81 \pm 3.71$ & $124.19 \pm 3.15$ & 11 & -2.637 & 0.271 \\
\hline $\mathrm{VO}_{2} \max (\mathrm{ml} / \mathrm{kg} / \mathrm{dk})$ & $47.41 \pm 1.56$ & $48.57 \pm 1.64$ & 11 & -3.739 & $0.028^{*}$ \\
\hline Speed $30 \mathrm{~m}(\mathrm{sn})$ & $4.74 \pm 0.27$ & $4.63 \pm 0.22$ & 11 & 2.285 & 0.156 \\
\hline Flexibility $(\mathrm{cm})$ & $25.85 \pm 2.65$ & $26.17 \pm 2.86$ & 11 & -4.187 & 0.229 \\
\hline
\end{tabular}

${ }^{*} \mathrm{p}<0.05$

Table 2 provides a comparison of pre-test and posttest measurement results of the control group. BFP

to be significant at $\mathrm{p}<0.05$ level. There was no and $\mathrm{VO}_{2}$ max values of the control group were found significant difference in the other data of the control group ( $p>0.05)$.

Table 3. Comparison of experimental and control groups

\begin{tabular}{|c|c|c|c|c|c|}
\hline Variable & $\begin{array}{c}\text { Experimental Group } \\
\text { Difference } \\
\text { Mean } \pm \text { SD }\end{array}$ & $\begin{array}{c}\text { Control Group } \\
\text { Difference } \\
\text { Mean } \pm \text { SD }\end{array}$ & $\mathrm{df}$ & $\mathrm{t}$ & $\mathrm{p}$ \\
\hline Weight (kg) & $0.79 \pm 1.12$ & $0.37 \pm 0.61$ & 22 & 2.026 & 0.122 \\
\hline BMI $\left(\mathrm{kg} / \mathrm{m}^{2}\right)$ & $0.87 \pm 0.72$ & $0.38 \pm 0.61$ & 22 & 1.184 & 0.384 \\
\hline $\mathrm{BFP}(\%)$ & $0.90 \pm 0.91$ & $0.57 \pm 0.28$ & 22 & 1.342 & 0.097 \\
\hline Anaerobic Power (kgm/sn) & $-11.29 \pm 5.87$ & $-0.38 \pm 1.76$ & 22 & -6.457 & $0.001^{*}$ \\
\hline $\mathrm{VO}_{2} \max (\mathrm{ml} / \mathrm{kg} / \mathrm{dk})$ & $-2.93 \pm 1.59$ & $-1.17 \pm 1.89$ & 22 & -2.881 & 0.068 \\
\hline Speed $30 \mathrm{~m}(\mathrm{sn})$ & $0.56 \pm 0.57$ & $0.11 \pm 0.52$ & 22 & 2.244 & $0.001^{*}$ \\
\hline Flexibility $(\mathrm{cm})$ & $-3.33 \pm 2.85$ & $-0.32 \pm 1.59$ & 22 & -5.674 & $0.001^{*}$ \\
\hline
\end{tabular}

The comparison of the measurement results of the experimental and control groups is presented in Table 3. Among the groups, significant differences were found in Anaerobic Power, Speed and DISCUSSION

In soccer trainings, sportsmen need plyometric training in order to be able to improve their strength, fast strength, leg strength and jumping efficiency. In individual sports and team sports, muscle power and muscular strength are determinative in successful performance. In addition, these exercises are effective in increasing the sportive performance of the sportsmen. Recently, plyometric trainings have been included in strength trainings $(13,23)$.

In our study, $\mathrm{BFP}$, anaerobic capacity, $\mathrm{VO}_{2} \max$, speed and elasticity values were found to be significant at $\mathrm{p}<0.05$ level after the plyometric training program of the experimental group. No other significance was found in the other data of the experimental group $(\mathrm{p}>0.05)$. $\mathrm{BFP}$ and $\mathrm{VO}_{2} \mathrm{max}$ values of the control group were found to be significant at $\mathrm{p}<0.05$ level. No other significance was found in the other data of the control group $(p>0.05)$.
Flexibility values in favor of the experimental group ( $p$ <.05). There was no significant difference in Weight, BMI, BFP and $\mathrm{VO}_{2}$ max values ( $\left.\mathrm{p}>0.05\right)$.

Among the groups, anaerobic capacity, speed and flexibility values were found to be significant in favor of the experimental group $(p<0.05)$. There was no significant difference in weight, BMI, BFP and $\mathrm{VO}_{2}$ max values $(\mathrm{p}>0.05)$. Physical activity results in a decrease in body fat mass. The rate of this decrease depends on the severity, frequency and type of the training (31).

In our study, BFP values were found to be significant after 8 weeks of plyometric training applied to the experimental group $(\mathrm{p}<0.05)$. Significance was also found in BFP values of the control group. Physical loadings provide that lean body masses increase from younger ages and thus the relative strength is constantly increased. In the literature, it is assumed that BFP generally decreases after physical activities $(12,14,20)$.

In a study conducted on judoists, a significant decrease was found in body fat percent after ten week pliometric training (33). Along with different 
outcomes, the general belief is that plyometric training does not have a significant effect on BFP values.

Potteiger et al. (1999) have not found any changes in body mass index and body composition after an 8 week plyometric training performed by physically active men (29).

In our study, the reduction in body fat percentage between pre-test and post-test of the experimental group was greater than that in the control group. It can be said that the cause of this is the decrease of body fat percentage and the increase of the muscle ratio by the effect of soccer training applied together with plyometric training.

Soccer is a sport that is highly aerobic and characterized by high intensity, intermittent exercises involving movements requiring a large number of negative and positive accelerations at different times, sprints, agility and jumps (30). Programmed, regular, correctly performed plyometric exercises have a positive effect on the performance of the sports branches (soccer, volleyball, basketball, handball, weightlifting etc.) where jumping plays an important role (11). Since jumping in plyometric trainings is performed within a very short time span, it provides both explosive characteristics and explosive power to improve (9).

In our study, significance at $p<0.05$ level was found in anaerobic power values after 8-week plyometric training applied to the experimental group. There was no significance in the control group.

Studies on plyometric trainings have shown that plyometric exercises performed in different types and severities significantly improve jumping performance. Al-Ahmad (1990) found in his study that 6-week plyometric training significantly increased the vertical jump values of basketball players when compared to the control group (1). In another study, a significant increase in the anaerobic capacity values of the subjects was detected in senior sportsmen aged 19-25 years at the end of plyometric training (17).

The values found in our study show similarity to the information given in the literature. In our study, it can be thought that the improvement in the experimental group's anaerobic capacity arose from the generation of explosive power by the help of explosive bounces for a very long time and increased muscle strength depending on this in their plyometric trainings.

Aerobic-based trainings increase $\mathrm{VO}_{2} \max$. Plyometric training does not improve $\mathrm{VO}_{2}$ max. It uses the phosphagen (ATP-CP) energy system using maximum power. During the plyometric trainings, if the association between rest and overload is not paid attention, the activity starts to become aerobic and the purpose of the plyometric training is lost (8).

In our study, $\mathrm{VO}_{2} \max$ values of the experimental and the control groups were found to be significant at $p<0.05$ level. This significance is thought to be due to the fact that the subjects' regular soccer trainings developed $\mathrm{VO}_{2}$ max values.

It has been suggested that speed is a genetic feature and one of the leading components of performance. Speed is in a complex structure such as reaction speed and movement as structure. Two most important factors affecting the speed of the soccer player are the state of the ball and the rival (24).

In our study, we found a significant difference at $p<0.05$ in the speed values of the experimental group after plyometric training program. There was no significance in the speed data of the control group. In a study conducted on young basketball players, an increase in sprint performance was observed after 8-week plyometric trainings in water and land (5). Another study detected significant improvement in long jump, vertical jump, flexibility, and 20-m sprint performances in the group performing strength trainings combined with plyometric training (3). It was seen that 25-m sprint performance of college sportsmen increased after 12week plyometric training (25).

Our study is in parallel with the information given in the literature. It can be said that the increase in speed in our experimental group is due to the plyometric training performed together with regular soccer training and nerve-muscle adaptations.

Flexibility is an ability that includes many different characteristics (joint structure, muscle structure, muscle mass, joint capsule, intramuscular and intercostal coordination, age, etc.). The biggest benefit of heavy power and strength trainings is to ensure muscles and the coordination between muscles to develop, resulting in increased strength and muscle growth (34). 
In our study, the flexibility values were found to be significant at $\mathrm{p}<0.05$ level after plyometric training program of the experimental group. Plyometric trainings affect the intermuscular and intramuscular coordination positively. The most important reason behind the increase in elasticity after plyometric trainings is the development of muscles and intramuscular coordination (7). Although there was an increase in flexibility values after ten week plyometric training applied to judo athletes, there was no significant difference (33). The general belief in the literature is that plyometric trainings improve flexibility. The information also supports the study conducted $(4,15,27)$.

It can be said that the improvement of flexibility in our experimental group is due to the development of the intermuscular and intramuscular coordination by the plyometric training.

\section{CONCLUSION}

As a result of our study, it is considered that the plyometric training program applied to young soccer players in addition to soccer training has a positive effect on the sportive performance parameters. Since plyometric trainings performed on a regular and programmed basis have a positive impact on sportive performance, it may be advisable to include plyometric trainings in soccer training programs.

\section{ACKNOWLEDGEMENTS}

This study is a part of Tahsin INCE's master thesis. We thank our Department of Physical Education and Sport in University of Gaziantep for their support in our study.

\section{REFERENCES}

1. AI-Ahmad A. The effects of plyometrics on selected physiological fitness parameters associated with high school basketball player,. The Florida State University, Dissertation Abstiacts International, 1990; 51: (2), 446-A.

2. American Thoracic Society American Collge of Chest Physicians. Am J Respir Crit Care Med. 2003; 167, 211-277.

3. Andrejić $O$. The effects of a plyometric and strength training program on the fitness performance in young basketball players, Facta universitatis-series: Physical Education and Sport, 2012; 10(3), 221-229.

4. Anıl F, Erol E, Pulur A. "Pliometrik Çalışmaların 14-16 Yaş Grubu Bayan Basketbolcuların Bazı Fiziksel ve Fizyolojik Parametreleri Üzerine Etkisi" Gazi Bed.Eğt. ve Spor Bilimleri Dergisi, 2001; 6(2) : 19-26.

5. Arazi H, Asadi A. The effect of aquatic and land plyometric training on strength, sprint, and balance in young basketball players, Journal of Human Sport \& Exercise, 2011; 6(1).

6. Aşçı $\mathrm{A}, \mathrm{Ak} \mathrm{M}$, Cihan $\mathrm{H}$. Genç futbolcularda aerobik güç performansının yaşa bağlı olarak değerlendirilmesi. S. Müniroğlu ve F. Korkusuz (Ed.). III. Ulusal Futbol ve Bilim Kongresi. Ankara: BAYT Bilimsel Araştırmalar 2009.

7. Ateş M, Demir M, Ateşoğlu U. Pliometrik antrenmanın 16-18 yaş grubu erkek futbolcuların bazı fiziksel ve fizyolojik parametreleri üzerine etkisi, Niğde Üniversitesi Beden Eğitimi ve Spor Bilimleri Dergisi, 2007; 1(1): 1-12.

8. Bayraktar I. Farklı Spor Branşlarında Pliometrik. Ata Ofset Matbaacilık, 2006: s.24.

9. Chu DA. Plyometrics, The Link Beetween Strength And Speed. Nsca Journal. 1983: 5: 20-21.

10. Chu DA. Jumping into Plyometries. IL: Leisure Press Champing. 1992.

11. Chu, D.A. Chu D. Jumping İnto Plyometrics, Human Kinetics Pub, Dimension, İllionois, August, 1998.

12. Coban A, Daglioglu O, Kaplan M, Ozdal M. The Investigation of Cardiac Functions and Blood Lipid Levels in Obese Men and Elite Athletes, Australian Journal of Basic and Applied Sciences, 7(12) Oct 2013, Pages: 340-347.

13. Dolu E. "Pliometrikler" Atletizm Bilim ve Teknoloji Dergisi. Sayı 13(1):5-9, Ankara, 1994.

14. Egana M, Done B. Physiological changes following a 12 week gym based stair-climbing, elliptical trainer and treadmill running program in female. J Sports Med Phys Fitness, 2004; 44: 141-146.

15. Erdoğan E, İnce A, Dinçer Ö, Sözen H, Cevahircioğlu B, Arı E. The Effect of Plyometric Training on Some Motor Skills of Studnets at Physical Education and Sports School. Prime Journal of Social Science. 2014; (3).12.

16. Fox Bowers, Foss. Beden Eğitimi ve Sporun Fizyolojik Temelleri, (Çeviri Cerit, M.,) Ankara: Bağırgan Yayınevi, 1999.

17. Günay M, Sevim Y, Savaş S, Erol A.E. Pliometrik çalışmaların sporcularda vücut yapısı ve sıçrama özelliklerine etkisi, H.Ü. Spor Bilimleri Dergisi, 1994; Cilt: 4, Sayı: 2, 38-4.

18. Hazır T, Mahir ÖF, Açıkada C. Genç futbolcularda çeviklik ile vücut kompozisyonu ve anaeorobik güç arasındaki ilişki, Hacettepe Spor Bilimleri Dergisi, 2010; 21(4): 146-153.

19. Hermassi S, Chelly MS, Tabka Z, Shephard RJ, Chamari K. Effects of 8 Weeks in Season Upper and Lower Limb Heavy Resistance Training on The Peak Power, Throwing Velocity, and Sprint Performance of Elite Male Handball Players. The Journal of Strength and Conditioning Research. 2011; 25(9). 2424-2433.

20. Inan B., Daglioglu O. Examination of children's body composition and biomotoric features which attended summer football schools, Turk J Sport Exe 2013; 15(2): 80-87.

21. İnal AN. Futbolda eğitim ve öğretim, 4. Baskı, Nobel yayınları, 2013. Ankara.

22. Köklü Y, Özkan A, Alemdaroğlu U, Ersöz, G. Genç futbolcuların bazı fiziksel uygunluk ve somatotip özelliklerinin oynadıkları mevkilere göre karşılaştırılması. 
Spormetre, Beden Eğitimi ve Spor Bilimleri Dergisi 2009, 7: 61-8

23. Little AD, Wilson GJ, Ostrowski KL. "Enhancing performance: maximal power versus weight and plyometrics training", Journal of Strength and Conditioning Research, 1996; 10:173-179.

24. Mantarcı B, Müniroğlu S. “Futbol Kalecileri ile Diğer Mevkilerde Bulunan Oyuncuların Motorik Özellikleri, Reaksiyon Zamanları ve Vücut Yağ Yüzdelerinin Karşılaştırılması" Gazi Beden Eğitimi ve Spor Bilimleri Dergisi, 2001; 6(3):13-26.

25. Moore EW, Hickey MS, and Reiser RF. Comparison of two twelve week off-season combined training programs on entry level collegiate soccer players' performance. J Strength Cond Res 19: 791-798, 2005.

26. Özkara A. Futbolda Testler ve Özel Çalışmalar. Ankara: Kuşçu Etiket ve Matbaacılık. 2004.

27. Öztin S, Erol AE, Pulur A. "15-16 Yaş Grubu-Basketbolculara Uygulanan Çabuk Kuvvet ve Pliometrik Çalışmaların Fiziksel ve Fizyolojik Özelliklere Etkisi" Gazi Beden Eğitimi ve Spor Bilimleri Dergisi, 2003; 8(1):41-52.
28. Piirainen JM, Cronin NJ, Avela J, Linnamo V. Effects of plyometric and pneumatic explosive strength training on neuromuscular function and dynamic balance control in 60-70 year old males. ItalianJournal of Anatomy and Embryology, 2014: 119(1): 10-19.

29. Potteiger JA, Lockwood RH, Haub MD, Dolezal BA, Almuzaini KS, Schroeder JM, and Zebas CJ. Muscle power and fiber characteristics following 8 weeks of plyometric training. J Strength Cond Res 1999;13: 275-279.

30. Shephard RJ. Biology and medicine of soccer, an update. Journal of Sports Sciences, 1999; 17, 757-786.

31. Stamford B. The Results Of Aerobic Exercise. The Physician And Sport Medicine, 1(9):145, 1983.

32. Tamer K. Sporda Fiziksel-Fizyolojik Performansının ölçülmesi ve Değerlendirilmesi. Türkerler Kitabevi, Ankara, 1995.

33. Uzun A, Karakoc O. The Effects of Ten Weekly Plyometric Training of Judokas on Anaerobic Power, Journal of Education and Training Studies, 5 (13), 2017; 52-58.

34. Ziyagil M.A, Tamer K, Zorba E. Beden Eğitimi ve Sporda Temel Motorik Özelliklerin ve Esnekliğin Geliştirilmesi, Emel Matbaacılık, Ankara, 1994. 